\title{
FORMATION OF SOURSOP SEEDLINGS IRRIGATED USING WATERS WITH DIFFERENT SALINITY LEVELS AND NITROGEN FERTILIZATION
}

\author{
FORMAÇÃO DE MUDAS DE GRAVIOLEIRA IRRIGADAS COM ÁGUAS DE \\ DISTINTAS SALINIDADES E ADUBAÇÃO NITROGENADA
}

\section{Luana Lucas de Sá Almeida VELOSO'; ${ }^{1}$ Reginaldo Gomes NOBRE²; Leandro de Pádua SOUZA³ Hans Raj GHEYI ${ }^{4}$; Ilana Taynan Saldanha CAVALCANTE ${ }^{5}$; Erbia Bressia Gonçalves ARAUJO' ${ }^{6}$; Wandra Laurentino da SILVA ${ }^{7}$}

1. Doutoranda em Engenharia Agrícola, Universidade Federal de Campina Grande - UFCG, Campina Grande, PB, Brasil; 2. Engenheiro Agrícola, Professor, Doutor, Universidade Federal de Campina Grande - CCTA/UFCG, Pombal, PB, Brasil; 3. Doutorando em Engenharia Agrícola, Universidade Federal de Campina Grande - UFCG, Campina Grande, PB, Brasil; 4. Professor, Doutor, UFCG, Programa de Pós-Graduação em Engenharia Agrícola, Campina Grande, PB, Brasil; 5. Graduanda em agronomia, UFCG, Pombal, PB, Brasil; 6. Mestranda em Horticultura Tropical, UFCG, Pombal, PB, Brasil; 7. Mestranda em Sistemas Agroindustriais, UFCG, Pombal, $\mathrm{PB}$, Brasil.

\begin{abstract}
Using saline waters in agriculture has become common in many regions worldwide, but some techniques have been developed to enable the use of these waters in order not to harm the crop. Thus, this study aimed to evaluate the growth of soursop seedlings, cv. 'Morada Nova', under interaction between salt stress and nitrogen (N) fertilization. The experiment was conducted in a greenhouse in randomized block design, in $5 \times 4$ factorial scheme, with 4 replicates, formed by the combination of five levels of irrigation water electrical conductivity - $\mathrm{ECw}(0.3 ; 1.1 ; 1.9 ; 2.4$ and $\left.3.5 \mathrm{dS} \mathrm{m}^{-1}\right)$ and four $\mathrm{N}$ doses $(70,100,130$ and $160 \%)$. The dose relative to $100 \%$ corresponded to $100 \mathrm{mg} \mathrm{of} \mathrm{N} \mathrm{dm}^{-3}$ of soil. The interaction between $\mathrm{N}$ doses and water salinity levels did not affect the seedling production stage of soursop, cv. 'Morada Nova'. The growth of 'Morada Nova' soursop seedlings subjected to different water salinity levels was less affected in the initial stage (45 days after treatment application). Water with ECw of $2.0 \mathrm{dS} \mathrm{m}^{-1}$ can be used to produce soursop seedlings, because it leads to an acceptable mean growth reduction of $10 \%$. $\mathrm{N}$ doses higher than $70 \mathrm{mg} \mathrm{dm}^{-3} \mathrm{do}$ not either attenuate salt stress or promote higher growth of soursop seedlings, cv. 'Morada Nova'.
\end{abstract}

KEYWORDS: Annona muricata L. Salt stress. Fertilization management.

\section{INTRODUCTION}

The Brazilian Northeast region has favorable weather conditions for various fruit species, including soursop (Annona muricata L.), which is one of the most important in the Annonaceae family in terms of economic expression in the region, due to its preference by the consumer (COSTA et al., 2008; SANTOS et al., 2014).

However, the Northeast region is characterized by low rainfalls and high evaporation rates, which naturally cause water deficit and increment in the saline concentrations of the water sources. Hence, the use of waters with high salt concentrations has become frequent and may compromise soil quality and crop yield (NEVES et al., 2009). In addition, combined with the climatic factors of the Northeast region, soil salinity has been increased due to inadequate management of irrigation and fertilization (HOLANDA FILHO et al., 2011).

Increment of saline concentration in the soil above the value tolerated by most species promotes negative effects that can be observed in the entire stand and can affect plants due to the reduction in the osmotic potential of the soil solution, ionic toxicity and nutritional imbalance, compromising physiological processes such as $\mathrm{CO}_{2}$ assimilation, synthesis of proteins and, in extreme cases, causing plant death, which limit the productive capacity, consequently resulting in serious damages to the agricultural activity (SOUSA et al., 2011).

Therefore, knowledge on the mean content of salts in the root zone tolerated by plants in the different growth stages can favor the use of waters with a certain level of salinity, very common in Northeast Brazil. Hence, it is indispensable to conduct studies aiming to obtain salinity tolerance indices of the crops, besides discovering techniques that mitigate the deleterious effects caused on crops by the high saline concentration in the irrigation water and/or soil (CAVALCANTE et al., 2010).

Among the techniques, nitrogen $(\mathrm{N})$ fertilization has been used to increase plant tolerance to salinity, due to the function of the nutrient in the production of amino acids, proteins, nucleic acids and chlorophylls, which favor such tolerance (LIMA et al., 2014). Del Amor et al. (2000) report that this nutrient can attenuate the effect of saline stress on cultures due to competition 
in absorption between the nitrate and chloride ions, that an increase in nitrate concentration in the root zone may inhibit increased absorption of chloride by the plant. Additionally, the accumulation of these organic solutes inside the cell may increase the osmotic adjustment capacity of the plants, helping and favoring the increment of tolerance to certain levels of water and salt stress (NASCIMENTO et al., 2015) producing better-quality seedlings to plant the orchard, increasing the establishment rate at the field, which is of great importance, especially in the first months after planting, when they are subjected to more-adverse environmental conditions (OLIVEIRA et al., 2014).

Studies on the interaction between irrigation water salinity and $\mathrm{N}$ rates have already been performed in some crops, such as guava (SILVA et al., 2017), castor (LIMA et al., 2014), cotton (SANTOS et al. 2016), among others.

In view of the above, this study aimed to evaluate the production of soursop seedlings irrigated with salinized waters and fertilized with different doses of Nitrogen.

\section{MATERIAL AND METHODS}

The experiment was carried out from December 2015 and April 2016, under protected environment conditions (greenhouse) in the experimental area of the Center of Sciences and Agrifood Technology of the Federal University of Campina Grande , Pombal county, Paraiba State, Brazil situated at $6^{\circ} 48^{\prime} 16^{\prime \prime} \mathrm{S}$ and $37^{\circ} 49^{\prime} 15^{\prime \prime} \mathrm{W}$, at an altitude of $144 \mathrm{~m}$.

Treatments were arranged in blocks in $5 \times 4$ factorial scheme, with four replicates and two plants per plot, resulting from the combination of five levels of irrigation water electrical conductivity (ECw) $\left(0.3 ; 1.1 ; 1.9 ; 2.7\right.$ and $\left.3.5 \mathrm{dS} \mathrm{m}^{-1}\right)$ associated with four doses of $\mathrm{N}$ fertilization $(70 ; 100 ; 130$ and $160 \%$ of the recommended dose). The dose relative to $100 \%$ corresponded to $100 \mathrm{mg}$ of $\mathrm{N} \mathrm{dm}^{-3}$ of soil, recommended by Novais et al. (1991). N fertilization was split into 13 weekly applications, from 7 days after total emergence of the seeds, using urea as $\mathrm{N}$ source $(45 \% \mathrm{~N})$.

The saline levels were selected based on recommendations of Cavalcante et al. (2001), who classified soursop in the initial growth stage as moderately sensitive to salinity, tolerating $\mathrm{ECw}$

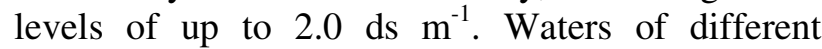
salinity levels were obtained by adding different quantities of $\mathrm{NaCl}, \mathrm{CaCl}_{2} \cdot 2 \mathrm{H}_{2} \mathrm{O}$ and $\mathrm{MgCl}_{2} \cdot 6 \mathrm{H}_{2} \mathrm{O}$ salts, at proportions equivalent to $7: 2: 1$, which prevails in the main water sources available for irrigation in Northeast Brazil (MEDEIROS, 1992).

The experiment used the soursop cultivar 'Morada Nova', which according to São José (2014) is a genetic material preferred by the farmers in the Northeast region, besides being the most used by the seedling nursery keepers. Seeds were obtained from a commercial orchard located in Sousa county, Paraiba State, Brazil. The seeds were manually extracted, dried in the shade and subjected to dormancy break.

Seeds were sown in plastic bags (height - 25 $\mathrm{cm}$, diameter $-13 \mathrm{~cm}$ ) with capacity for $1.2 \mathrm{~kg}$, which had holes at the bottom to allow free drainage. After filling, the bags were arranged on metal benches at a height of $0.8 \mathrm{~m}$ from the soil.

The bags were filled with substrate composed of soil + sand + bovine manure (wellaged) at proportion (in volume) of 82, 15 and 3\%, respectively, and the cattle manure was added in such a quantity so as not to mask treatment effects, but aiming only to improve soil physical, chemical and

Soil physical and chemical characteristics of the Eutrophic Fluvic Neosol collected at depth of 0$20 \mathrm{~cm}$ was (Table 1) were determined according to Donagema et al. (2011) at the and Plant Nutrition Laboratory of the Centro de Ciências e Tecnologia Agroalimentar (CCTA) da Universidade Federal de Campina Grande (UFCG). Bovine manure was added to improve physical characteristics of the substrate, but without interfering with the results of the variables.

Sowing was performed on December 12, 2015 , by planting two seeds per bag at depth of 1.5 $\mathrm{cm}$. Emergence started 20 days after sowing (DAS) and settled 40 DAS. At 5 days after total emergence, thinning was performed to leave only the most vigorous plant per bag, which was conducted until the seedling stage.

During the period of emergence, the substrate was maintained with moisture close to field capacity, using public-supply water $(\mathrm{ECw}$ of $0.3 \mathrm{dS} \mathrm{m}^{-1}$ ).

The Different saline levels started to be applied at 7 days after stabilization emergence process (DAE), through daily and manual irrigation held late afternoon and according to the treatments. Irrigations were performed based on plant water demand, determined by drainage lysimetry.

Every 15 days, a leaching fraction of 0.15 was applied based on the volume applied during this period, as recommended by Ayers \& Westcot (1999), which takes into account soil texture. 
Table 1. Physical and chemical characteristics of the substrate used in the experiment.

\begin{tabular}{|c|c|c|c|c|c|c|c|c|c|}
\hline \multirow{3}{*}{$\begin{array}{c}\text { Textural } \\
\text { classification }\end{array}$} & \multirow{3}{*}{\multicolumn{2}{|c|}{$\begin{array}{r}\text { Bulck } \\
\text { density } \\
\mathrm{g} \mathrm{cm}^{-3} \\
\end{array}$}} & \multirow{3}{*}{$\begin{array}{c}\text { Total } \\
\text { porosity } \\
\%\end{array}$} & \multirow{3}{*}{$\begin{array}{c}\text { Organic } \\
\text { matter } \\
\mathrm{gkg}^{-1}\end{array}$} & \multirow{3}{*}{$\begin{array}{c}\mathrm{P} \\
\mathrm{mg} \mathrm{dm}^{-3}\end{array}$} & \multicolumn{4}{|c|}{ Sortive complex } \\
\hline & & & & & & $\mathrm{Ca}^{2+}$ & $\mathrm{Mg}^{2+}$ & $\mathrm{Na}^{+}$ & $\mathrm{K}^{+}$ \\
\hline & & & & & & \multicolumn{4}{|c|}{$---\mathrm{cmol}_{\mathrm{c}} \mathrm{dm}^{-3}$} \\
\hline Sandy franc & 1.38 & & 47.00 & 32 & 17 & 5.4 & 4.1 & 2.21 & 0.28 \\
\hline \multicolumn{10}{|c|}{ Saturation extract } \\
\hline $\mathrm{CE}_{\mathrm{es}}$ & $\mathrm{Ca}^{2+}$ & $\mathrm{Mg}^{2+}$ & $\mathrm{K}^{+}$ & $\mathrm{Na}^{+}$ & $\mathrm{SO}_{4}{ }^{2-}$ & $\mathrm{CO}_{3}{ }^{2-}$ & \multirow[t]{2}{*}{$\mathrm{HCO}_{3}^{-}$} & \multirow{2}{*}{\multicolumn{2}{|c|}{$\begin{array}{c}\text { Saturation } \\
\%\end{array}$}} \\
\hline $\mathrm{dS} \mathrm{m} \mathrm{m}^{-1}$ & & ------ & -------- & ---- $\mathrm{mmol}_{\mathrm{c}} \mathrm{dm}^{-3}$ & ------- & --- & & & \\
\hline 7.41 & 2.50 & 3.75 & 4.74 & 7.50 & 3.10 & 0.00 & 5.63 & & .00 \\
\hline
\end{tabular}

Cultivation practices along the experiment consisted of weeding and superficial scarification of the substrate to remove the compacted layer, besides preventive management against pests and diseases, through sprayings with the recommended commercial products.

At 45 and 90 days after applying the treatments (DAT), growth variables were evaluated: plant height $(\mathrm{PH})$, stem diameter (SD), number of leaves (NL), leaf area (LA), shoot dry phytomass (SDP) and leaf area ratio (LAR). Absolute (AGRSD) and relative (RGR-SD) growth rates of stem diameter were evaluated in the intervals of $15-45$ and 15-90 DAT.

$\mathrm{PH}$ was determined by measuring the plants from soil surface to the insertion of apical meristem. SD was measured at height of $3 \mathrm{~cm}$ above the soil level (mm), while NF was determined considering leaves whose blades were fully expanded.

LA was determined as recommended by Almeida et al. (2006), through Eq. 1, where LA = leaf area $\left(\mathrm{dm}^{2}\right)$ and $\mathrm{x}=$ product between length and width $(\mathrm{cm})$.

$$
\mathrm{LA}=5.71+0.647 \mathrm{x}\left(\mathrm{R}^{2}=0.91\right) \quad \text { Eq. } 1
$$

In the periods 15-45 and 15-90 DAT, AGRSD and RGR-SD were determined according to the methodology proposed by Benincasa (2003), using Eq. 2 and 3, respectively.

AGR_SD $=\frac{\left(\mathrm{SD}_{2}-\mathrm{SD}_{1}\right)}{\left(\mathrm{t}_{2}-\mathrm{t}_{1}\right)} \quad$ RGR_SD $=\frac{\left(\operatorname{lnSD}_{2}-\operatorname{lnSD_{1}}\right)}{\left(\mathrm{t}_{2}-\mathrm{t}_{1}\right)}$

Where:

AGR_SD = absolute growth rate of stem diameter $\left(\mathrm{mm} \mathrm{day}^{-1}\right)$,

RGR_SD = relative growth rate of stem diameter $\left(\mathrm{mm} \mathrm{mm}^{-1}\right.$ day $\left.^{-1}\right)$,

$\mathrm{SD}_{1}=$ stem diameter $(\mathrm{mm})$ at time $\mathrm{t}_{1}$,

$\mathrm{SD}_{2}=$ stem diameter $(\mathrm{mm})$ at time $\mathrm{t}_{2}$,

$\ln =$ natural logarithm.
LAR was determined according to Eq. 4

(BENINCASA, 2003).

$$
\begin{aligned}
& \text { LAR }=\frac{L A}{S D M}=\left(\mathrm{dm}^{2} \mathrm{~g}^{-1}\right) \\
& \text { Where: } \\
& \text { SDM: shoot dry matter }(\mathrm{g}) \\
& \text { LA: leaf area }\left(\mathrm{dm}^{2}\right)
\end{aligned}
$$

The variables were evaluated using analysis of variance by $\mathrm{F}$ test ( 0.05 probability level) and, in cases of significant effect, linear and quadratic polynomial regression analyses were performed using the statistical software SISVAR. The regression model was selected based on the best fit, coefficient of determination $\left(\mathrm{R}^{2}\right)$ and considering a probable biological explanation (FERREIRA, 2011).

\section{RESULTS AND DISCUSSION}

Based on the analysis of variance analysis (Table 2), there was no significant interaction effect between the factors, irrigation water salinity and $\mathrm{N}$ (S $x$ ND) or nitrogen fertilization (ND) in the studied variables. However, there was a significant effect only for irrigation water salinity levels ( $p>$ $0.01)$ at plant height $(\mathrm{PH})$ and stem diameter (SD) of graviola plants at 45 and 90 DAT and in the area foliar (LA) and number of leaves (NL) at 90 DAT.

According to the regression equations (Figure 1), the increase in irrigation water salinity promoted a quadratic effect $(\mathrm{p}<0.01)$ on plant height at 45 and 90 DAT, with increments up to the ECw levels of $1.6 \mathrm{dS} \mathrm{m} \mathrm{m}^{-1}(34.68 \mathrm{~cm})$ and $1.5 \mathrm{dS} \mathrm{m}^{-1}$ $(44.09 \mathrm{~cm})$, respectively, and reductions from these values of electrical conductivity. Hence, given the reductions in $\mathrm{PH}$, soursop seedlings exhibit sensitivity to water salinity. Water deficit, induced by the osmotic effect, may have caused 
morphological and anatomical alterations in the plants to the point of compromising water absorption and transpiration rate (SILVA et al., 2008).

Table 2. Summary of the analysis of variance for plant height (PH), stem diameter (SD), leaf area (LA) and number of leaves (NL) of soursop seedlings at 45 and 90 days after applying the treatments (DAT).

\begin{tabular}{|c|c|c|c|c|c|c|c|c|c|}
\hline \multirow{3}{*}{ TREATMENTS } & \multirow[b]{3}{*}{ FD } & \multicolumn{6}{|c|}{ MIDDLE SQUARE } & \multirow{2}{*}{\multicolumn{2}{|c|}{$\mathrm{NL}$}} \\
\hline & & \multicolumn{2}{|c|}{$\mathrm{PH}$} & \multicolumn{2}{|c|}{ SD } & \multicolumn{2}{|c|}{ LA } & & \\
\hline & & 45 & 90 & 45 & 90 & 45 & 90 & 45 & 90 \\
\hline Salinity (S) & 4 & $28.51^{* *}$ & $108.79^{* *}$ & $1.02^{* *}$ & $2.62^{* *}$ & $1.07^{\mathrm{ns}}$ & $8.64^{* *}$ & $4.23^{\mathrm{ns}}$ & $34.29^{* *}$ \\
\hline Linear reg. & 1 & $24.41^{\mathrm{ns}}$ & $146.30^{*}$ & $0.01^{\mathrm{ns}}$ & $0.82^{\text {ns }}$ & $2.06^{\mathrm{ns}}$ & $25.77^{* *}$ & $6.07^{\mathrm{ns}}$ & $90.13^{* *}$ \\
\hline Quadratic reg. & 1 & $82.57^{* *}$ & $230.04^{* *}$ & $3.17^{* *}$ & $8.61^{* *}$ & $1.51^{\mathrm{ns}}$ & $3.14^{\mathrm{ns}}$ & $6.48^{\mathrm{ns}}$ & $40.02^{* *}$ \\
\hline $\mathrm{N}$ dose $(\mathrm{DN})$ & 3 & $2.96^{\mathrm{ns}}$ & $58.33^{\mathrm{ns}}$ & $0.13^{\mathrm{ns}}$ & $0.74^{\mathrm{ns}}$ & $0.86^{\mathrm{ns}}$ & $1.79^{\mathrm{ns}}$ & $3.77^{\mathrm{ns}}$ & $1.00^{\mathrm{ns}}$ \\
\hline Linear reg. & 1 & $2.13^{\mathrm{ns}}$ & $3.37^{\mathrm{ns}}$ & $0.39^{\mathrm{ns}}$ & $2.18^{*}$ & $0.27^{\mathrm{ns}}$ & $1.18^{\mathrm{ns}}$ & $1.61^{\mathrm{ns}}$ & $2.61^{\mathrm{ns}}$ \\
\hline Quadratic rę̧ & 1 & $2.19^{\mathrm{ns}}$ & $30.31^{\mathrm{ns}}$ & $2 \times 10^{-3} \mathrm{~ns}$ & $0.02^{\mathrm{ns}}$ & $1.32^{\mathrm{ns}}$ & $0.61^{\mathrm{ns}}$ & $3.26^{\mathrm{ns}}$ & $0.26^{\mathrm{ns}}$ \\
\hline Interaction $(S \times D N)$ & 12 & $6.83^{\mathrm{ns}}$ & $23.63^{\mathrm{ns}}$ & $0.04^{\text {ns }}$ & $0.36^{\text {ns }}$ & $0.89^{\text {ns }}$ & $4.01^{\mathrm{ns}}$ & $7.38^{\mathrm{ns}}$ & $8.29^{\mathrm{ns}}$ \\
\hline Block & 3 & $427.32^{* *}$ & $658.87^{* *}$ & $9.08^{* *}$ & $6.11^{* * *}$ & $2.76^{*}$ & $2.37^{\mathrm{ns}}$ & $2.21^{\mathrm{ns}}$ & $0.95^{\mathrm{ns}}$ \\
\hline $\mathrm{CV}(\%)$ & & 11.65 & 12.83 & 8.83 & 8.88 & 20.94 & 19.86 & 14.36 & 10.3 \\
\hline
\end{tabular}

ns, ${ }^{* *}, *$ respectively not significant, significant at $\mathrm{p}<0.01$ and $\mathrm{p}<0.05$

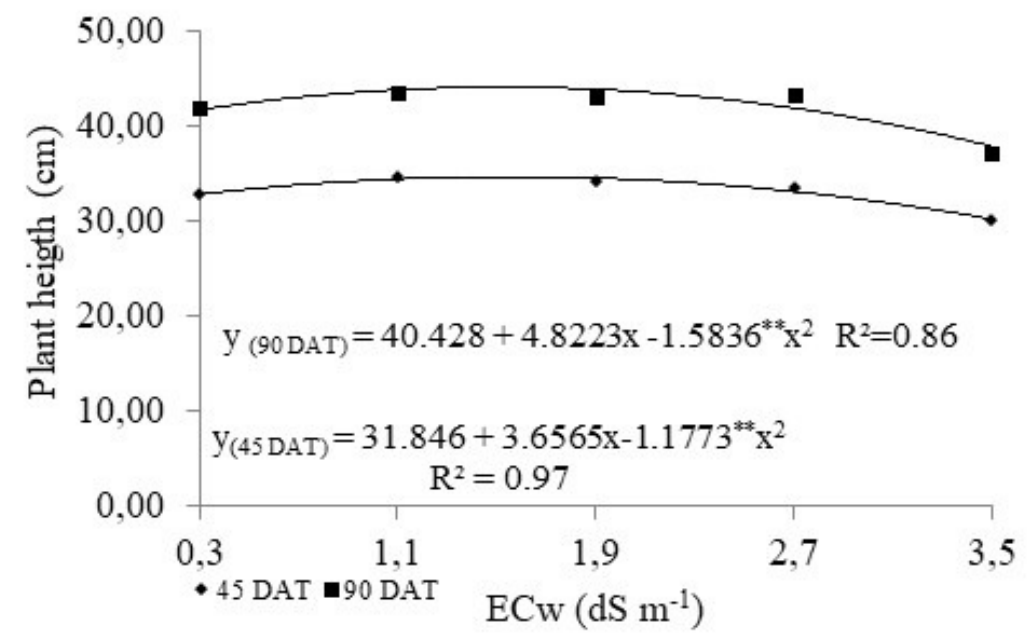

Figure 1. Plant height - $\mathrm{PH}$ at 45 and 90 days after applying the treatments - DAT. as a function of irrigation water salinity - ECw.

The increase in irrigation water salinity led to reduction $(\mathrm{p}<0.01)$ in stem diameter at 45 and 90 DAT. Based on the regression equations (Figure 2), there was a quadratic behavior and the highest SD values $(5.84$ and $7.05 \mathrm{~mm}$ ) were obtained at $\mathrm{ECw}$ of 1.9 and $1.6 \mathrm{dS} \mathrm{m}^{-1}$, respectively. Initially, soursop plants had higher tolerance to stress, i.e., up to 45 DAT. According to Cavalcante et al. (2001), such superiority does not indicate that soursop seedlings can be produced using water with saline concentration equal to or higher than $1.9 \mathrm{dSm}^{-1}$, because successive irrigations may increase the saline character of the substrate to the point of reaching values not tolerated by the crop and, consequently, increase losses of seedling quality. This result was observed at 90 DAT, since the tolerance was reduced at $\mathrm{ECw}=1.6 \mathrm{dS} \mathrm{m}^{-1}$. Such reduction in stem diameter is a response to the stomatal closure and decrease in transpiration and, consequently, decrease in the absorption of water and nutrients by plants, resulting in lower growth (LIMA et al., 2015). 


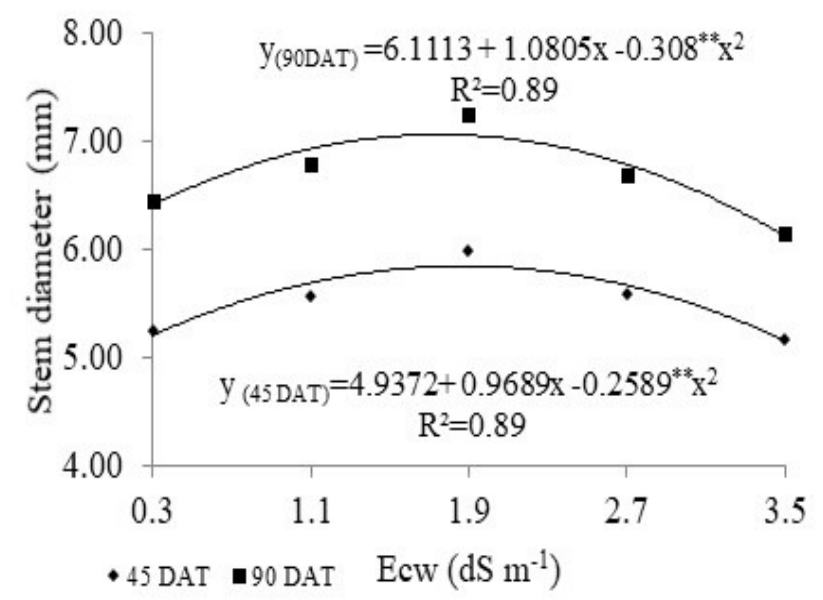

Figure 2. Stem diameter - SD at 45 and 90 days after applying the treatments - DAT. as a function of irrigation water salinity - ECw.

Leaf area was affected by the salt stress $(\mathrm{p}<0.01)$ only at 90 DAT (Table 2$)$ and, according to the regression equation (Figure 3), showed a linear reduction of $7.23 \%$, i.e., $0.058 \mathrm{dm}^{2}$ per unit increase in $\mathrm{ECw}$, i.e., plants subjected to $\mathrm{ECw}$ of 3.5 $\mathrm{dS} \mathrm{m}^{-1}$ reduced their leaf area by $1.85 \mathrm{dm}^{2}$ in comparison to those under $0.3 \mathrm{dS} \mathrm{m}^{-1}$. As the time of exposure to the salts increases, plants become exposed to a higher degree of water retention, reaching a point that they do not have enough energy to absorb water at the rate necessary to perform their metabolic activities. Thus, under water deficit conditions induced by the osmotic stress, morphological and anatomical alterations commonly occur in the plants, such as smaller leaves and lower number of leaves, which also contributed to a lower water consumption by the plant (COELHO et al., 2013; NOBRE et al., 2014).

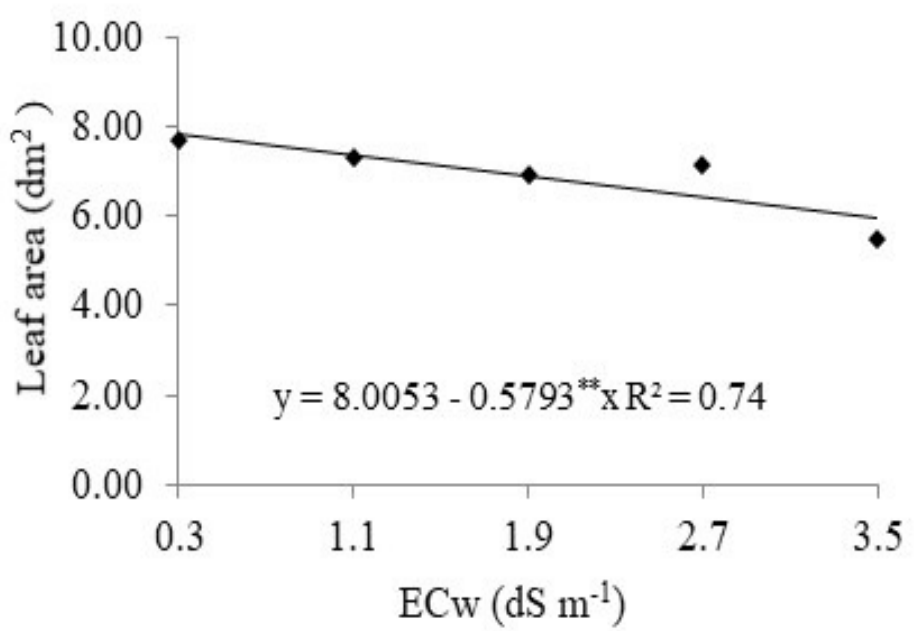

Figure 3. Leaf area - LA at 90 days after applying the treatments - DAT. as a function of irrigation water salinity - ECw.

According to Figure 4, for the number of leaves (NL) at 90 DAT, the data fitted best to a quadratic model, due to the increase in $\mathrm{ECw}$. The highest value (18.86) was obtained when plants were irrigated using water with $\mathrm{ECw}$ of $1.2 \mathrm{dS} \mathrm{m}^{-1}$. The reduction in the number of leaves may result from adaptation mechanisms of the plant to salt stress, reducing the transpiring surface. Hence, reduction in the number of leaves under such conditions is relevant to maintain high water potential in the plant (NOBRE et al., 2014). 


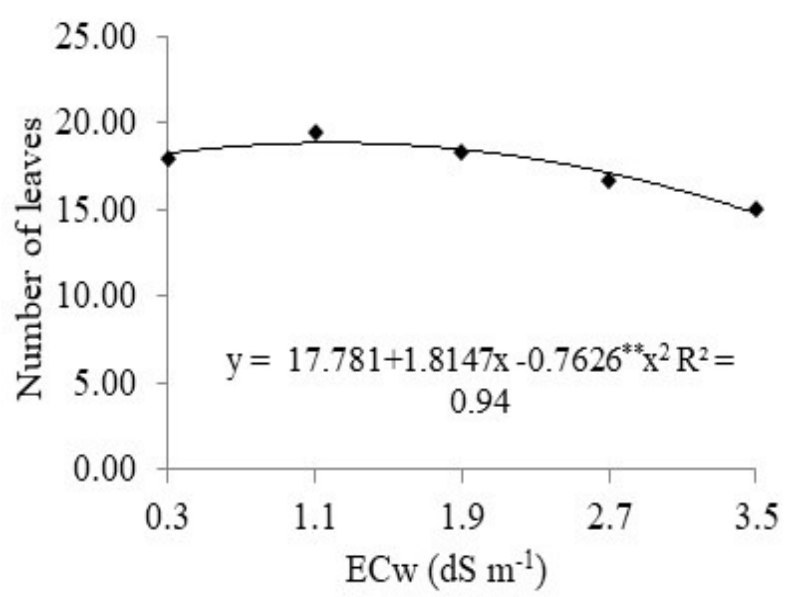

Figure 4. Number of leaves - NL at 90 days after applying the treatments - DAT. as a function of irrigation water salinity - ECw.

As shown in Table 3, water salinity had significant effect on the absolute growth rate from 15 to 45 DAT and from 15 to 90 DAT. On the other hand, there was significant effect of water salinity on the relative growth rate from 15 to 90 DAT and on leaf area ratio at $90 \mathrm{DAT}$. For the factor $\mathrm{N}$ doses, as well as the interaction between factors (water salinity $\mathrm{x} \mathrm{N}$ doses), there was no significant effect ( $p>0.05$ ) on any of the studied variables.

Table 3. Summary of the analysis of variance for absolute (AGR-SD) and relative (RGR-SD) growth rates of stem diameter from 15 to 45 and from 15 to 90 days after applying the treatments (DAT). shoot dry phytomass (SDP) at 90 DAT and leaf area ratio (LAR) of soursop seedlings at 45 and 90 DAT. irrigated using waters with different salinity levels and nitrogen fertilization.

\begin{tabular}{|c|c|c|c|c|c|c|c|c|}
\hline \multirow{3}{*}{ TREATMENTS } & \multirow[b]{3}{*}{ GL } & \multicolumn{7}{|c|}{ MIDDLE SQUARE } \\
\hline & & \multicolumn{2}{|c|}{ AGR-SD } & \multicolumn{2}{|c|}{ RGR-SD } & \multirow{2}{*}{$\begin{array}{l}\text { SDP } \\
90\end{array}$} & \multicolumn{2}{|c|}{ LAR } \\
\hline & & 15 à45 & 15 à 90 & 15 à 45 & $15 a ̀ ~ 90$ & & 45 & 90 \\
\hline Salinity (S) & 4 & $3 \times 10^{-4^{*}}$ & $2 \times 10^{-4^{* *}}$ & $9 \times 10^{6 n s}$ & $5 \times 10^{-6^{*}}$ & $0.88^{* *}$ & $16.76^{* * *}$ & $733.22^{\mathrm{ns}}$ \\
\hline Linear reg. & 1 & $2 \times 11^{-4 n s}$ & $3 \times 10^{-4 *}$ & $1 \times 10^{-5 \mathrm{~ns}}$ & $1 \times 10^{-5^{*}}$ & $1.98^{* *}$ & $35.11^{* *}$ & $1747.88^{\mathrm{ns}}$ \\
\hline Quadratic reg. & 1 & $6 \times 10^{-4 *}$ & $6 \times 10^{-4 * *}$ & $1 \times 10^{-5 n s}$ & $7 \times 10^{-6 *}$ & $1.52^{* *}$ & $28.98^{* *}$ & $981.39^{\mathrm{ns}}$ \\
\hline $\mathrm{N}$ dose (DN) & 3 & $1 \times 10^{-4 \mathrm{~ns}}$ & $9 \times 10^{-5 n s}$ & $5 \times 10^{-6 n s}$ & $2 \times 10^{-6 n s}$ & $0.11^{\mathrm{ns}}$ & $3.63^{\mathrm{ns}}$ & $42.17^{\mathrm{ns}}$ \\
\hline Linear reg. & 1 & $1 \times 10^{-4 \mathrm{~ns}}$ & $2 \times 10^{-4 \mathrm{~ns}}$ & $8 \times 10^{-6 \mathrm{~ns}}$ & $6 \times 10^{-6 \mathrm{~ns}}$ & $0.002^{\mathrm{ns}}$ & $0.001^{\mathrm{ns}}$ & $41.02^{\mathrm{ns}}$ \\
\hline Quadratic reg. & 1 & $2 \times 10^{-6 \mathrm{~ns}}$ & $1 \times 10^{-5 n s}$ & $1 \times 10^{-6 \mathrm{~ns}}$ & $1 \times 10^{-6 n s}$ & $0.002^{\mathrm{ns}}$ & $4.25^{\mathrm{ns}}$ & $6.79^{\mathrm{ns}}$ \\
\hline Interaction $(\mathrm{S} \times \mathrm{DN})$ & 12 & $6 \times 10^{-5 n s}$ & $7 \times 10^{-5 n s}$ & $4 \times 10^{-6 \mathrm{~ns}}$ & $2 \times 10^{-\mathrm{sns}}$ & $0.04^{\mathrm{ns}}$ & $2.82^{\mathrm{ns}}$ & $103.14^{\mathrm{ns}}$ \\
\hline Block & 3 & $4 \times 10^{-4 *}$ & $3 \times 10^{-5 n s}$ & $9 \times 10^{-6 n s}$ & $1 \times 10^{-4 * *}$ & $0.86^{\mathrm{ns}}$ & $6.39 *$ & $487.94^{\mathrm{ns}}$ \\
\hline $\mathrm{CV}(\%)$ & & 34.98 & 20.44 & 18.96 & 19.72 & 13.63 & 21.32 & 12.57 \\
\hline
\end{tabular}

$\mathrm{ns}, * *, *$ respectively not significant, significant at $\mathrm{p}<0.01$ and $\mathrm{p}<0.05$. Statistical analysis performed after the transformation of shoot dry phytomass (SDP) at 90 DAT and leaf area ratio (LAR) at 45 and 90 DAT data to $\sqrt{\mathrm{x}}$.

The AGR-SD was influenced by the increment in irrigation water salinity and, according to the regression equations (Figure 5A), quadratic behavior occurred in both intervals of evaluation (15-45 and 15-90 DAT). In the period corresponding to the interval of 15-45 DAT, the highest value of AGR-SD (0.033 mm day $\left.{ }^{-1}\right)$, as observed for stem diameter, occurred when the seedlings were subjected to $\mathrm{ECW}$ of $1.9 \mathrm{dS} \mathrm{m}^{-1}$. Already in the interval of 15-90 DAT, the highest value $\left(0.039 \mathrm{~mm} \mathrm{day}^{-1}\right)$ was observed at ECw of 2.0 $\mathrm{dS} \mathrm{m} \mathrm{m}^{-1}$. The reduction of growth from this point on
(1.9 and $2.0 \mathrm{dS} \mathrm{m}^{-1}$, respectively) may be associated with the energy expenditure for the synthesis of osmotically active organic compounds necessary to the processes of compartmentalization in the regulation of the transport of ions (LOPES \& KLAR 2009).

Based on the regression equation (Figure $5 B)$, the increment in irrigation water salinity caused decreasing linear effect on RGR-SD in the period of 15-90 DAT, in which plants irrigated using water with EC of $3.5 \mathrm{dS} \mathrm{m}^{-1}$ showed reduction of 0.007 $\mathrm{mm} \mathrm{mm} \mathrm{m}^{-1}$ day $^{-1}(17.53 \%)$ in the RGR-SD, in 
comparison to those under $0.3 \mathrm{dS} \mathrm{m} \mathrm{m}^{-1}$. Reduction in relative growth may result from the increasing accumulation of salts in the soil due to irrigation along the experimental period, which negatively contributed to the water absorption by plants due to the osmotic effect and/or toxic effect of the salts on plants, leading to reduction of growth (TRAVASSOS et al., 2012), because the plant stand was not uniform, leaves were burned on the edges and their color were not characteristic of the crop.
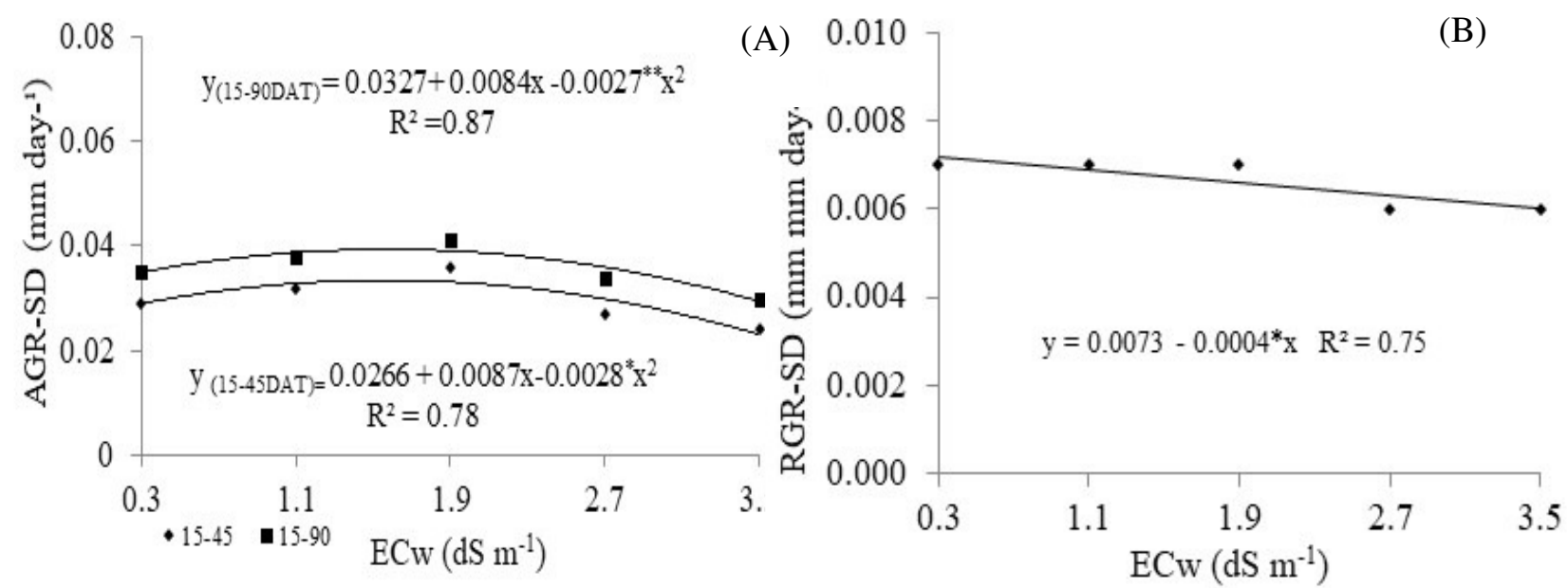

Figure 5. Absolute growth rate of stem diameter - AGR-SD (A) in the periods of 15-45 and 15-90 DAT; Relative growth rate of stem diameter - RGR-SD (B) in the period of 15-90 DAT of soursop seedlings as a function of irrigation water salinity - ECw.

According to the regression equation shown in Figure 6A. shoot dry phytomass (SDP) exhibited a quadratic response as $\mathrm{ECw}$ increased from 0.3 (public-supply water) to $3.5 \mathrm{dS} \mathrm{m}^{-1}$, showing maximum value of $6.42 \mathrm{~g}$ in plants irrigated using water with $\mathrm{ECw}$ of $1.3 \mathrm{dS} \mathrm{m}^{-1}$. When plants were irrigated using water with $\mathrm{ECw}$ of $3.5 \mathrm{dS} \mathrm{m}^{-1}$, there was a reduction of $2.80 \mathrm{~g}$ in SDP, compared with those under $1.3 \mathrm{dS} \mathrm{m}^{-1}$. This reduction in phytomass (at 90 DAT) expresses the sensitivity character of soursop in the tolerance to water salinity. Reduction

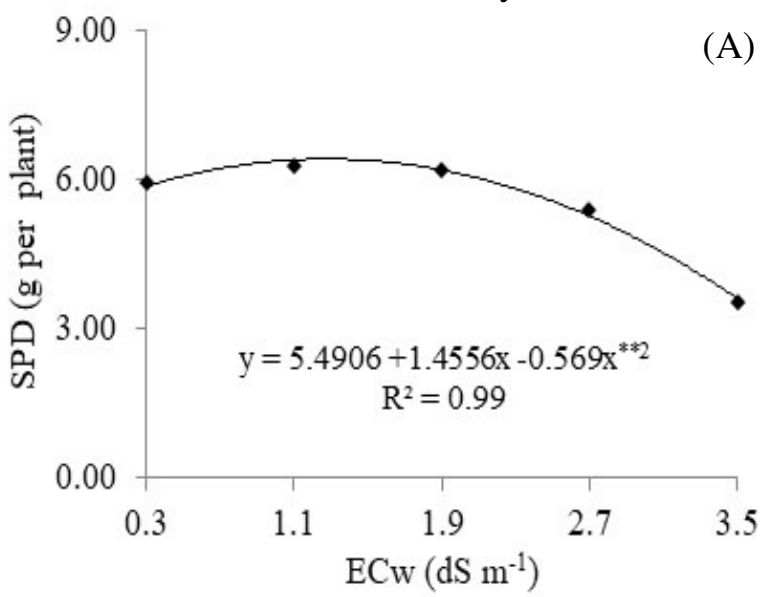

of shoot dry phytomass under such conditions is important to maintain high water potential in the plant, obtained through the reduction in transpiration, because the increase in soil solution saline concentration reduces the osmotic potential of the soil, compromising water absorption by plants and causing negative effects of nutritional order, of toxicity and/or interfering with the availability of other ions (LIMA et al., 2014).

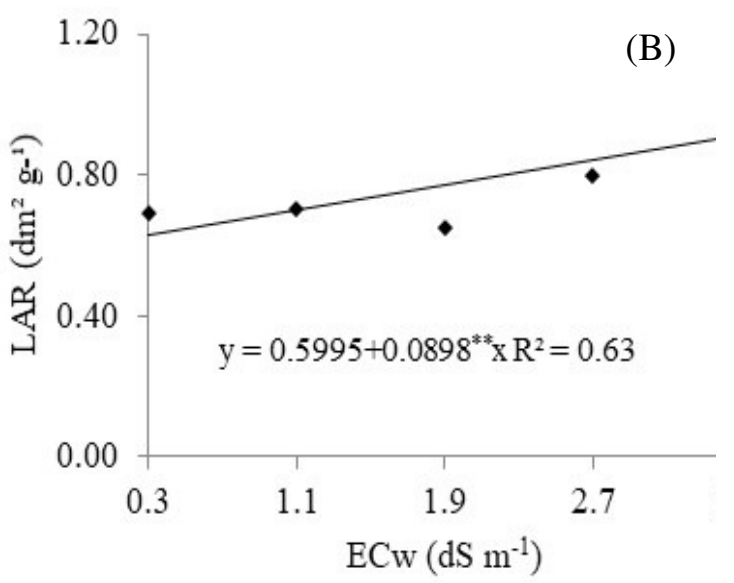

Figure 6. Shoot dry phytomass - SDP (A) and leaf area ratio - LAR (B) at 90 DAT in soursop seedlings as a function of irrigation water salinity - ECw. 
As demonstrated in Table 3, LAR was influenced $(p<0.01)$ by the increment in irrigation water salinity only at 45 DAT and, according to the regression equation (Figure 6B), it showed a linear increment of $14.97 \%$ per unit increase in $\mathrm{ECw}$, i.e., increment of $0.28 \mathrm{dm}^{2}(52.89 \%)$ in plants under ECw of $3.5 \mathrm{dS} \mathrm{m}^{-1}$ in comparison to those irrigated with public-supply water. At 45 DAT, plants under the highest water salinity levels showed greater amount of photosynthesizing material in relation to shoot dry matter. This fact may be related to the adjustment in the water potential of the crop, allowing water absorption under these conditions (COELHO et al., 2014).

\section{CONCLUSIONS}

The interaction between $\mathrm{N}$ doses and water salinity levels did not affect the seedling production stage of soursop. cv. 'Morada Nova'.

The growth of soursop seedlings. cv. 'Morada Nova', subjected to different levels of water salinity was less affected in the initial stage (45 DAT).

Water with ECw of $2.0 \mathrm{dS} \mathrm{m}^{-1}$ can be used to produce soursop seedlings, because it leads to an acceptable mean growth reduction of $10 \%$.

$\mathrm{N}$ doses higher than $70 \mathrm{mg}$ of $\mathrm{N} \mathrm{dm}^{-3}$ of soil do not either attenuate salt stress or promote greater growth of soursop seedlings. cv. 'Morada Nova'.

RESUMO: O uso de águas salinas na agricultura tornou-se um fato corriqueiro em diversas regiões do mundo. Contudo algumas técnicas têm sido desenvolvidas para viabilizar o uso dessas águas de modo a não prejudicar a cultura. Neste sentido, objetivou-se avaliar o crescimento de mudas de gravioleira cv. Morada Nova sob interação entre a salinidade da água de irrigação e adubação nitrogenada. Desenvolvida em casa de vegetação em delineamento de blocos casualizados em esquema fatorial 5 x 4, com quatro repetições, constituído pela combinação de cinco condutividade elétrica da água de irrigação $\operatorname{CEa}\left(0.3 ; 1.1 ; 1.9 ; 2.4\right.$ e $\left.3.5 \mathrm{dS} \mathrm{m}^{-1}\right)$ e quatro doses $(70,100,130$ e $160 \%$ de nitrogênio). Sendo a dose referente a $100 \%$, correspondente a $100 \mathrm{mg}$ de $\mathrm{N}$ por $\mathrm{dm}^{-3}$ de solo. A interação entre os fatores doses de nitrogênio e níveis de salinidade da água não afetaram a fase de produção de mudas de gravioleira cv. Morada Nova. O crescimento das mudas de gravioleira cv. Morada Nova, submetidas a diferentes níveis de salinidade da água foi menos comprometido pela salinidade na fase inicial (45 Dias após aplicação dos tratamentos). Na produção de mudas de gravioleira pode-se usar água de CEa de até $2.0 \mathrm{dS} \mathrm{m}^{-1}$ pois proporciona redução média aceitável de $10 \%$ no crescimento. Doses de nitrogênio superior a $70 \mathrm{mg} \mathrm{de} \mathrm{N} \mathrm{dm}^{-3}$ de solo não atenuam o estresse salino nem promovem maior crescimento de mudas de gravioleira cv. Morada Nova.

PALAVRAS-CHAVE: Annona muricata L. Estresse salino. Nitrogênio e salinidade.

\section{REFERENCES}

ALMEIDA, G. D. de; SANTOS, J. G. dos; ZUCOLOTO, M.; VICENTINI, V. B.; MORAES, W. B.; BREGONCIO; I. S. dos, COELHO, R. I. Estimativa de área foliar de graviola (Annona muricata L.) por meio de dimensões lineares do limbo foliar. Revista UNIVAP, v. 1, n. 24, p. 1035-1037, 2006.

BENINCASA, M. M. P. Análise de crescimento de plantas: noções básicas. 2. ed. Jaboticabal, SP: FUNEP, 2003, 41p.

CAVAlCANTE, L. F.; CARVALHO, S. D.; LIMA, E. D.; FEITOSA FILHO, J. C.; SILVA, D. A desenvolvimento inicial da gravioleira sob fontes e níveis de salinidade da água. Revista Brasileira de Fruticultura, v. 23, n. 2, p. 455-459, 2001. http://dx.doi.org/10.1590/s0100-29452001000200053

CAVALCANTE, L. F.; VIEIRA, M. S.; SANTOS, A. F.; OLIVEIRA, W. M.; NASCIMENTO, J. A. M. Água salina e esterco bovino líquido na formação de mudas de goiabeira cultivar Paluma. Revista Brasileira de Fruticultura, v. 32, n. 1, p. 251-261, 2010. http://www.scielo.br/scielo.php?pid=S0100$29452010000100030 \&$ script $=$ sci_abstract\&tlng=pt

CLAESSEN, M. E. C. (org.). Manual de métodos de análise de solo. 2. ed. revista atual. Rio de Janeiro: Embrapa-CNPS, (Embrapa-CNPS. Documentos, 1),1997, p. 212. 
COELHO, J. B. M.; BARROS, M. F. C.; BEZERRA NETO, E.; CORREA, M. M. Comportamento hídrico e crescimento do feijão vigna cultivado em solos salinizados. Revista Brasileira de Engenharia Agrícola e Ambiental, v. 17, n. 4, p. 379-385, 2013. http://dx.doi.org/10.1590/s1415-43662013000400004

COELHO, D. S.; SIMÕES, W. L.; MENDES, A. M. S.; DANTAS, B. F.; RODRIGUES, J. A. S.; SOUZA, M. A. de. Germinação e crescimento inicial de variedades de sorgo forrageiro submetidas ao estresse salino. Revista Brasileira de Engenharia Agrícola e Ambiental, v. 18, n. 1, p. 25-30, 2014. http://dx.doi.org/10.1590/s1415-43662014000100004

COSTA, A. M. G.; COSTA, J. T. A.; JUNIOR, A. T. C.; CORREIA, D.; MEDEIROS FILHO, S. Influência de diferentes combinações de substratos na formação de porta-enxertos de gravioleira (Annona muricata L.).

Revista Ciência Agronômica, v. 36, n. 3, p. 299-305, 2008.

http://ccarevista.ufc.br/seer/index.php/ccarevista/article/view/241

DEL AMOR, F. M.; RUIZ-SANCHEZ, M. C.; MARTINEZ, V.; CERDA, A. Gás Exchange, water relations, and ions concentrations of saltstressed tomato and melon plants. Journal of Plant Nutrition, v. 23, n. 9, p. 1315- 1325, 2000. https://www.tandfonline.com/doi/abs/10.1080/01904160009382102.

FERREIRA, D. F. Sisvar: Um sistema computacional de análise estatística. Ciência e Agrotecnologia, v. 35, n. 6, p. 1039-1042, 2011. http://dx.doi.org/10.1590/s1413-70542011000600001

HOLANDA FILHO, R. S. DE; SANTOS, D. B. DOS; AZEVEDO, C. A. DE; COELHO, E. F.; LIMA, V. L. DE. Água salina nos atributos químicos do solo e no estado nutricional da mandioqueira. Revista Brasileira de Engenharia Agrícola e Ambiental, v. 15, n. 1, p. 60-66, 2011. http://dx.doi.org/10.1590/s141543662011000100009

LIMA, G. S. de; NOBRE, R. G.; GHEYI, H. R.; SOARES, L. A. A. dos; SILVA, S. S. da. Respostas morfofisiológicas da mamoneira, em função da salinidade da água de irrigação e adubação nitrogenada. Irriga, v. 19, n. 1, p. 130-136, 2014. http://dx.doi.org/10.15809/irriga.2014v19n1p130

LIMA, L. A.; OLIVEIRA, F. D. A. de; ALVES, R. C. de; LINHARES, P. S. F.; MEDEIROS, A. M. A. de; BEZERRA, F. M. S. Tolerância da berinjela à salinidade da água de irrigação. Revista Agroambiente, v. 9, n. 1, p. 27-34, 2015. http://dx.doi.org/10.18227/1982-8470ragro.v9i1.2202

LOPES, T. C.; KLAR, A. E. Influência de diferentes níveis de salinidade sobre aspectos morfofisiológicos de mudas de Eucalyptus urograndis. Irriga, v. 14, n. 1, p. 68-75, 2009.

MEDEIROS, J. F. Qualidade da água de irrigação e evolução da salinidade nas propriedades assistidas pelo "GAT" nos Estado do RN, PB e CE. 1992. 173 f. Dissertação (Mestrado) - Universidade Federal da Paraíba, Campina Grande, 1992.

NASCIMENTO, H. H. C.; SANTOS, C. A. DOS; FREIRE, C. S.; SILVA, M. A. DA; NOGUEIRA, R. J. M. C. Ajustamento osmótico em mudas de jatobá submetidas à salinidade em meio hidropônico. Revista Árvore, v. 39, n. 4, p. 641-653, 2015. http://dx.doi.org/10.1590/0100-67622015000400006

NEVES, A. L. R.; LACERDA, C. F.; GUIMARÃES, F. V. A.; HERNANDEZ, F. F. F.; SILVA, F. B., PRISCO, J. T.; GHEYI, H. R. Acumulação de biomassa e extração de nutrientes por plantas de feijão-de-corda irrigadas com água salina em diferentes estádios de desenvolvimento. Ciência Rural, v. 39, n. 3, p. 758-765, 2009. http://dx.doi.org/10.1590/S0103-84782009005000014.

NOBRE, R. G.; LIMA, G. S. DE; GHEYI, H. R.; SOARES, L. A. A. DOS; OLIVEIRA, A. S. Consumo e eficiência do uso da água pela mamoneira sob estresse salino e nitrogênio. Revista Caatinga, v. 27, n. 2, p. 148-158, 2014. https://periodicos.ufersa.edu.br/index.php/caatinga/article/view/2739. 
NOVAIS, R. F.; NEVES, J. C. L.; BARROS, N. F. Ensaio em ambiente controlado. In: OLIVEIRA, A. J. Ensaio em ambiente controlado. In: OLIVEIRA A. J. (ed). Métodos de pesquisa em fertilidade do solo. Brasília-DF: Embrapa - SEA, 1991, p. 189-253.

SANTOS, H. H. D; MATOS, V. P.; ALBUQUERQUE, A. P. C. DA; SENA, L. H. M. DE; FERREIRA, E. G. B. S. DE. Morfologia de frutos, sementes e plântulas de AVERRHOA BILIMBI L. Oriundas de dois estágios de maturação. Ciência Rural, v. 44, n. 11, p. 1995-2002, 2014. http://dx.doi.org/10.1590/0103-8478cr20130992.

SANTOS, J. B.; GHEYI, H. R.; LIMA, G. S.; XAVIER, D. A.; CAVALCANTE, L. F.; CENTENO, C. R. M. MORFOFISIOLOGIA E PRODUÇÃO DO ALGODOEIRO HERBÁCEO IRRIGADO COM ÁGUAS SALINAS E ADUBADO COM NITROGÊNIO. Comunicata Scientiae (online), v. 7, p. 86, 2016. https://doi.org/10.14295/cs.v7i1.1158.

SILVA, E. M. DA; NOBRE, R. G.; SOUZA, L. DE P. ; ARAÚJO, R. H. C. R.; PINHEIRO, F. W. A.; ALMEIDA, L. L. DE S. MORFOFISIOLOGIA DE PORTA-ENXERTO DE GOIABEIRA IRRIGADO COM ÁGUAS SALINIZADAS SOB DOSES DE NITROGÊNIO. COMUNICATA SCIENTIAE, v. 8, n.1, p. 32, 2017. https://doi.org/10.14295/cs.v8i1.1547.

SILVA, S. M.; ALVES, A. N.; GHEYI, H. R.; BELTRÃO, N. D. M.; SEVERINO, L. S.; SOARES, F. A. DESENVOLVIMENTO E PRODUÇÃO DE DUAS CULTIVARES DE MAMONEIRA SOB ESTRESSE SALINO. REVISTA BRASILEIRA DE ENGENHARIA AGRÍCOLA E AMBIENTAL, v. 12, n. 4, p. 335342, 2008. http://dx.doi.org/10.1590/s1415-43662008000400001.

SOUSA, A. B. O.; BEZERRA, M. A. FARIAS, F. C. GERMINAÇÃO E DESENVOLVIMENTO INICIAL DE CLONES DE CAJUEIRO COMUM SOB IRRIGAÇÃO COM ÁGUA SALINA. . REVISTA BRASILEIRA DE ENGENHARIA AGRÍCOLA E AMBIENTAL, v. 15, n. 4, p. 390-394, 2011. http://dx.doi.org/10.1590/s1415-43662011000400010.

TRAVASSOS, K. D.; GHEYI, H. R.; SOARES, F. A. L.; BARROS, H. M. M.; DIAS, N. SILVA da; UYEDA, C. A.; SILVA, F. V. DA. CRESCIMENTO E DESENVOLVIMENTO DE VARIEDADES DE GIRASSOL IRRIGADO COM ÁGUA SALINA. Irriga, v. 1, n. 1, p. 324-339, 2012.

http://dx.doi.org/10.15809/irriga.2012v1n01p324. 